\title{
Physicochemical and Sensory Analysis of Commercial Honeys of Apis Mellifera Produced by Cooperative Societies in Mexico City
}

\author{
Aida Huerta Barrientos", Laura P. Avila Callejas, Alma E. Vera Morales, Miguel A. Saldaña Cabrera, \\ Eduardo García López, Emiliano Gutiérrez Ayala
}

Department of Operations Research, Faculty of Engineering, UNAM, 04510, México.

\begin{abstract}
How to cite this paper: Aida Huerta Barrientos, Laura P. Avila Callejas, Alma E. Vera Morales, Miguel A. Saldaña Cabrera, Eduardo García López, Emiliano Gutiérrez Ayala. (2020) Physicochemical and Sensory Analysis of Commercial Honeys of Apis Mellifera Produced by Cooperative Societies in Mexico City. International Journal of the Science of Food and Agriculture, 4(3), 338-347.

DOI: $10.26855 /$ ijfsa.2020.09.014
\end{abstract}

Received: August 24, 2020

Accepted: September 20, 2020

Published: October 10, 2020

*Corresponding author: Aida Huerta Barrientos, Department of Operations Research, Faculty of Engineering, UNAM, 04510, México.

Email: aida.huerta@comunidad.unam.mx

\begin{abstract}
In Mexico, there are different organization and associative figures that group beekeepers nationally as well as locally. An specific kind of social organization for Mexican Beekeepers is the cooperative society figure, which is formed by persons based on common interests and on the principles of solidarity, self-effort and mutual aid, with the purpose of satisfying individual and collective needs, through the performance of economic activities of production, distribution and consumption of goods and services related with beekeeping. In Mexico City, there are three cooperative societies specialized in beekeeping, however, limited information about the quality of commercial honeys of Apis Mellifera that is produced and marketed by such cooperative is limited or does not exist. Therefore, the purpose of this study is to contribute to the knowledge of the quality of commercial honeys of Apis Mellifera that is produced and marketed by cooperative societies in Mexico City, through a sensory and a physicochemical analysis. The color, water content, electrical conductivity, $\mathrm{pH}$, total acidity, free acidity, lactone, and reducing sugars profile as well as the sensory characteristics were analyzed. All tested honey samples were within the Official Mexican Standard and the Codex Alimentations, 2001 limit, except cooperative society 2 honey and cooperative society 3 honey in water content value and cooperative society 1 honey in lactone value. This study concludes that the commercial honey of Apis Mellifera produced and marketed by the three cooperative societies in Mexico City had a good level of quality.
\end{abstract}

\section{Keywords}

Physicochemical Analysis, Honey, Mexico City, Urban Apiculture

\section{Introduction}

Honey is defined as the natural sweet substance produced by honey bees, from the nectar of plant flowers and honey dew [1]. Physical and chemical characteristics of bee honey mainly depend on the diversity of the plants from which they are harvested,geographical floral origin, climatic conditions, soil type, environmental conditions, bee race and treatment of beekeepers [2, 3]. Fromnutritional view, honey contains at least 200 compounds, major and minors, but mainly carbohydrates and water [4]. Honey also contains enzymes, amino acids, proteins, flavonoids, phenolic acids, organic acids, vitamins, and minerals in lower quantities [5]. The chemical composition of honey varies from a sample to another and usually contains major and minor compounds [4] which work by interacting with each other to produce a range of synergistic antioxidant properties [5]. Information on the honey therapeutic properties has been investigated [5] 
denoting that honey possesses antioxidant [6, 7, 8], antidiabetic [8], fertility [8], antibacterial [9,10,11,12,13], antiviral, anti-inflammatory [9, 14], antiulcerous [5], immunemodulating [5], vasodilative [5], hypotensive [5], hypocholesterolemic [5], and antitumor activities [8, 9, 15].

Mexico has a long history of honey production, it is an activity that has been practiced for several centuries and nowadays represents an important source of income in rural areas [15]. Based on the different climates and flora, which have the composition of nectar and pollen, Mexico is a divided into five well-defined honey production regions, producing different types of honey in terms of physical and chemical characteristics. The five regions are shown in Figure 1.

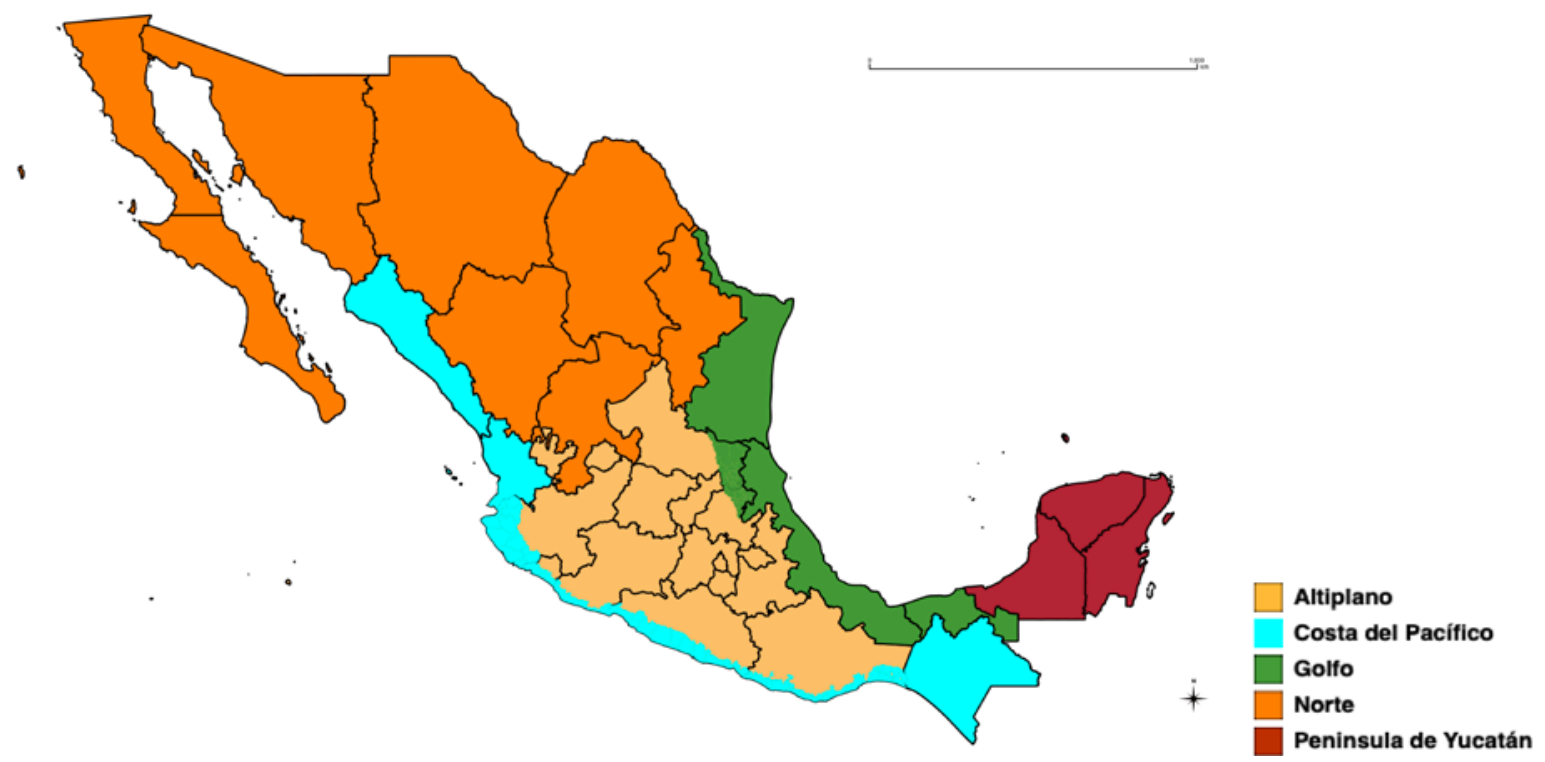

Figure 1. Five well-defined beekeeping regions in Mexico, from General Livestock Coordination of the Secretariat of Rural Development (SADER).

The honey production in Mexico from the period 1960-2017 is showed in Figure 2. In 2010, Mexico ranked sixth in the world of honey and third as an exporter, mainly to the European market [17]. Unfortunately, in the last years, the amount of production has been decreasing by the lack of measures to potentiate this sector. In 2016, there were 45,000 producers engaged in beekeeping nationwide who work with 1.859 million hives while in 2017, there were 43,478 producers working with 1.853 million hives. In the last decade, the honey production in Mexico City has been over 70 tons annually (see Figure 3) produced by 4,000 hives located in six municipalities: Alvaro Obregón, Magdalena Contreras, Milpa Alta, Tláhuac, Tlalpan y Xochimilco.

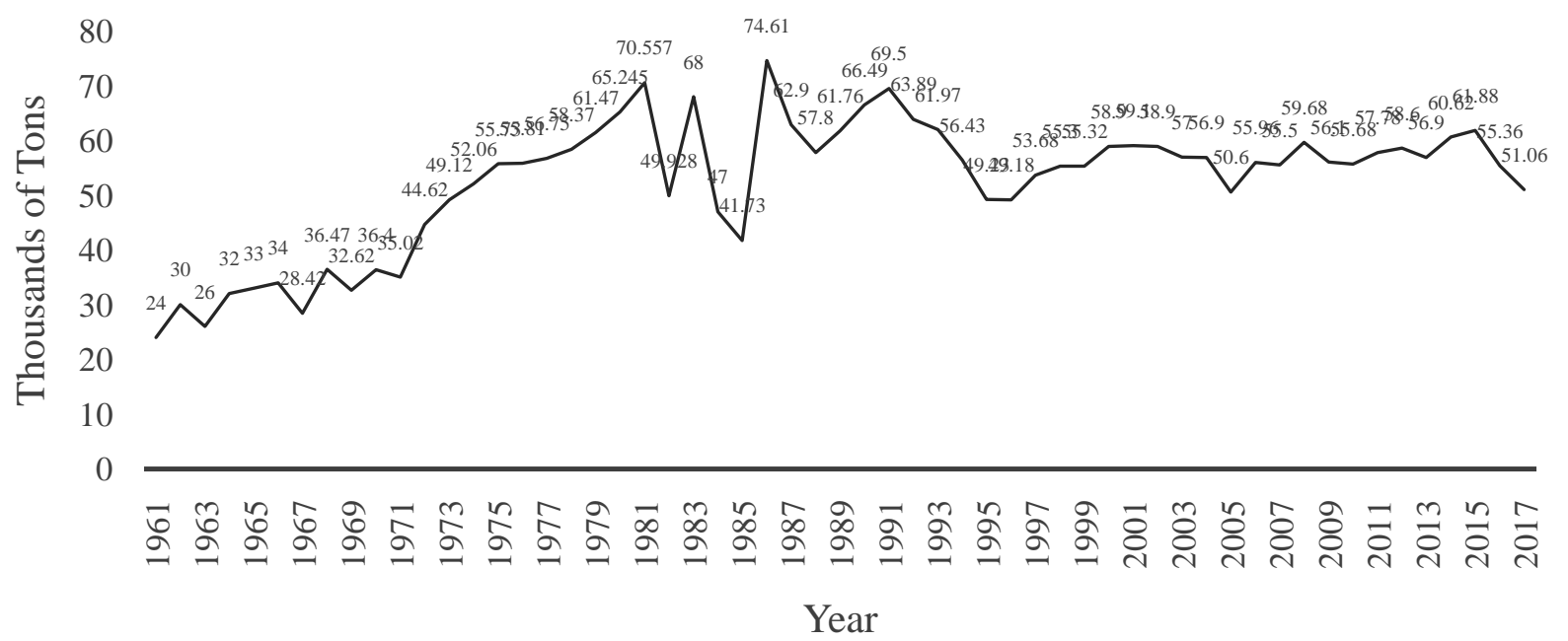

Figure 2. Plot of honey production in Mexico from the period 1960-2017 with respect to time, from General Livestock Coordination of the Secretariat of Rural Development (SADER). 


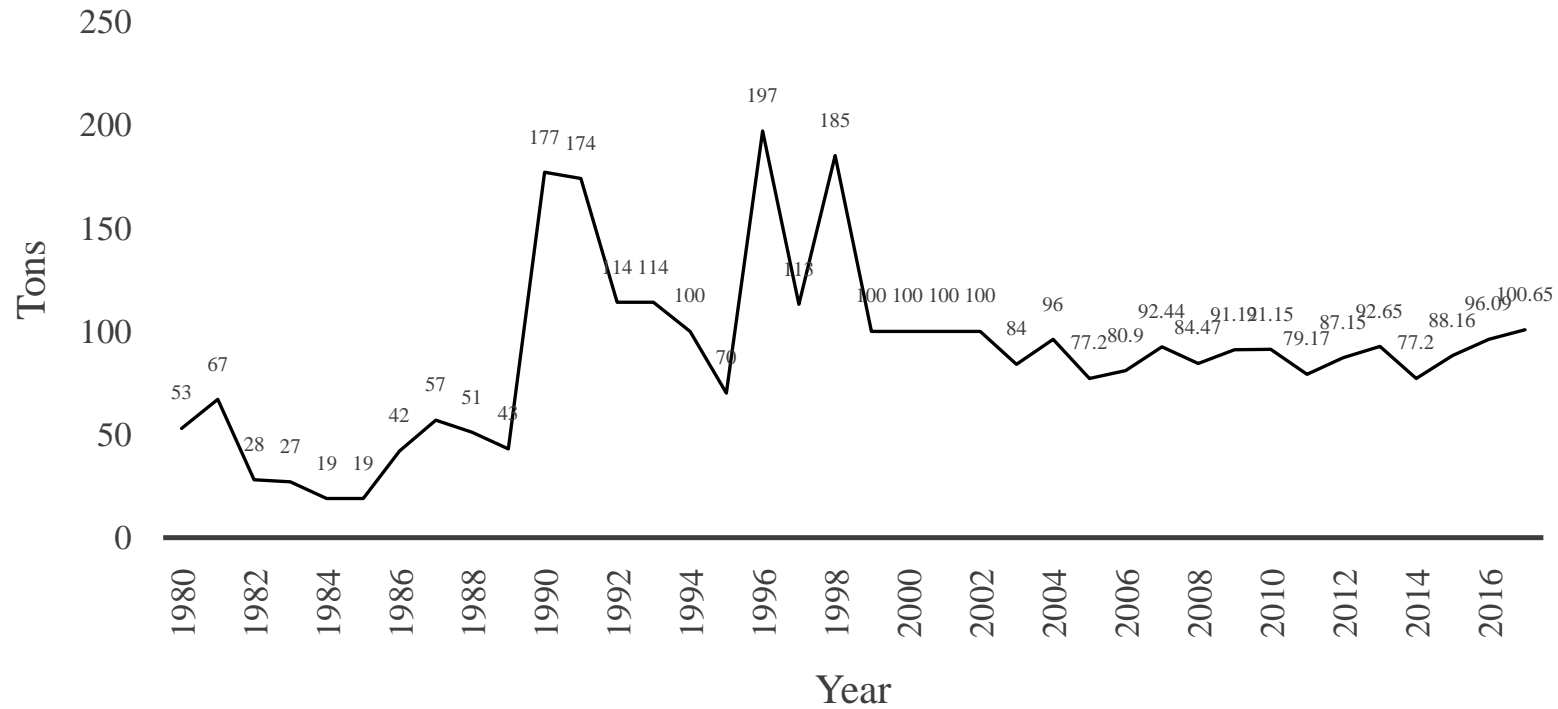

Figure 3. Plot of honey production in Mexico City from the period 1980-2017 with respect to time, from General Livestock Coordination of the Secretariat of Rural Development (SADER).

Nowadays, there are different organization and associative figures that group beekeepers nationally as well as locally. According to Atlas Nacional de las Abejas y Derivados Apícolas 2017 [18], Mexican beekeepers are registered in 508 livestock associations specialized in beekeeping and 110 associations of other types. An specific kind of social organization for Mexican Beekeepers is the cooperative society figure, which is formed by persons based on common interests and on the principles of solidarity, self-effort and mutual aid, with the purpose of satisfying individual and collective needs, through the performance of economic activities of production, distribution and consumption of goods and services related with beekeeping. In Mexico City, there are three cooperative societies specialized in beekeeping [19]: Cepra Miel SC de RL de CV, ApiarioAtotolco SC de RL de CV, Construir en Raices SC de RL de CV. The beekeeping value chain for each one is showed in Figures 4-6. It is important to note that each cooperative includes innovation process in their value chain.

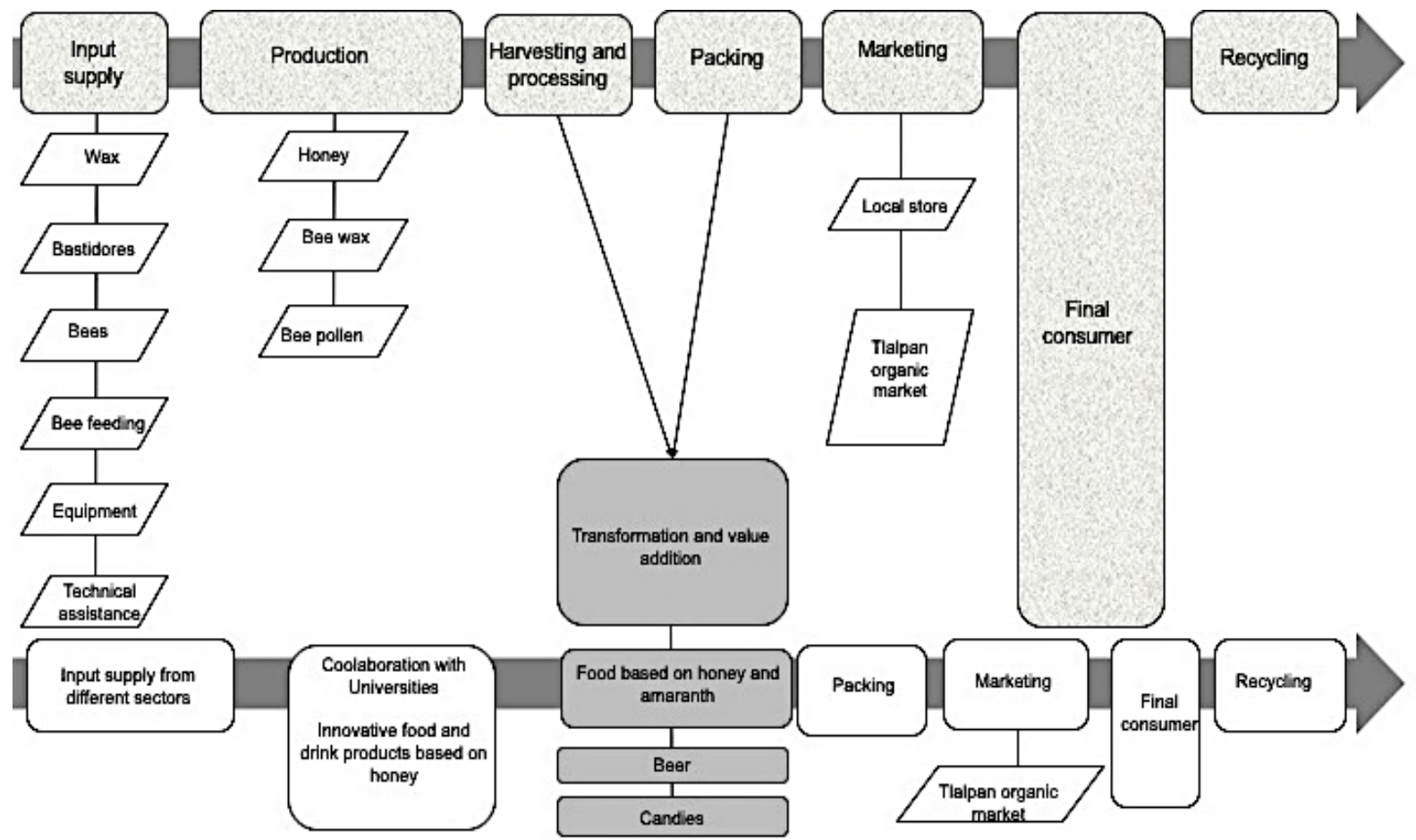

Figure 4. Value chain cooperative society Construir en Raices SC de RL de CV. 


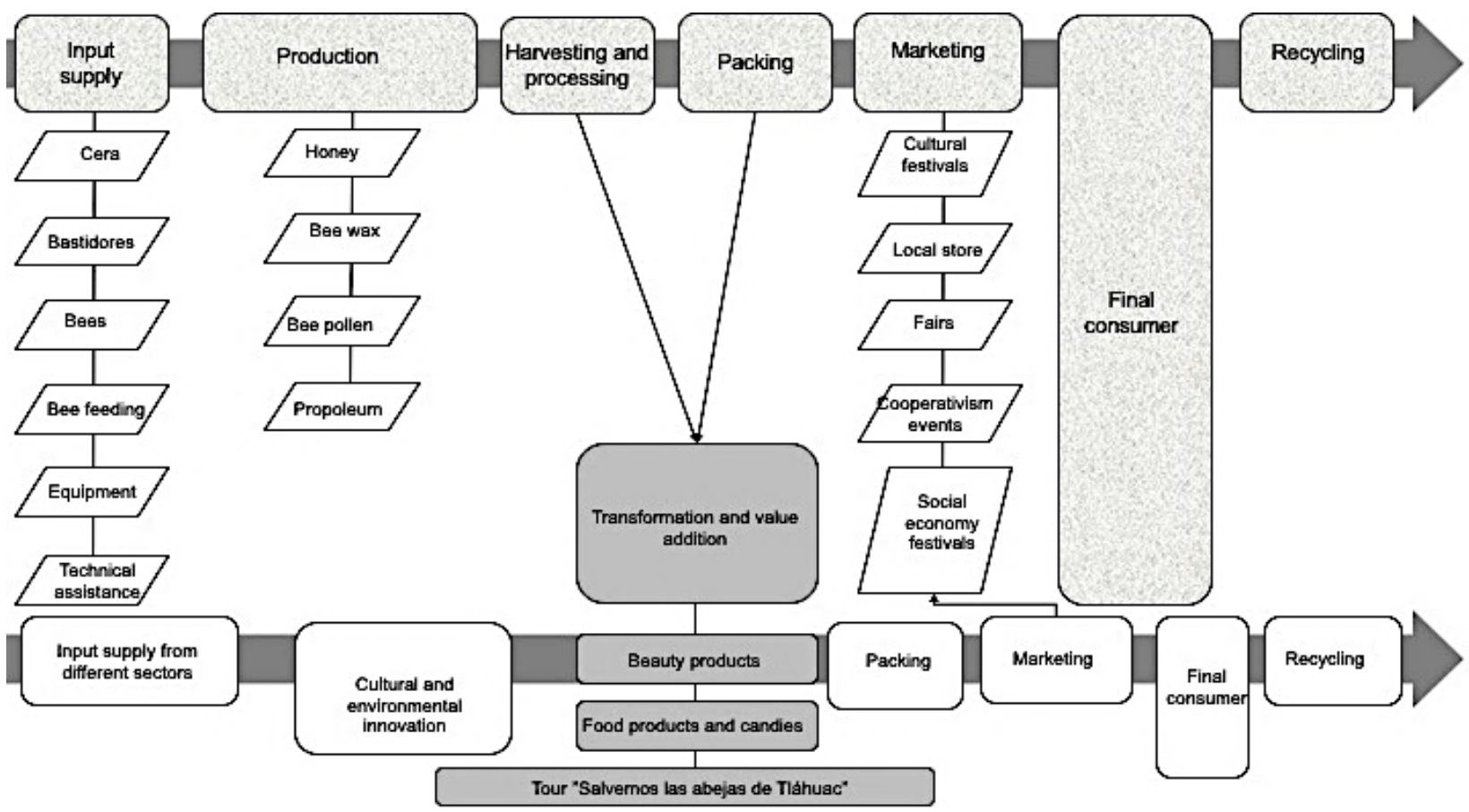

Figure 5. Value chain cooperative society ApiarioAtotolco SC de RL de CV.

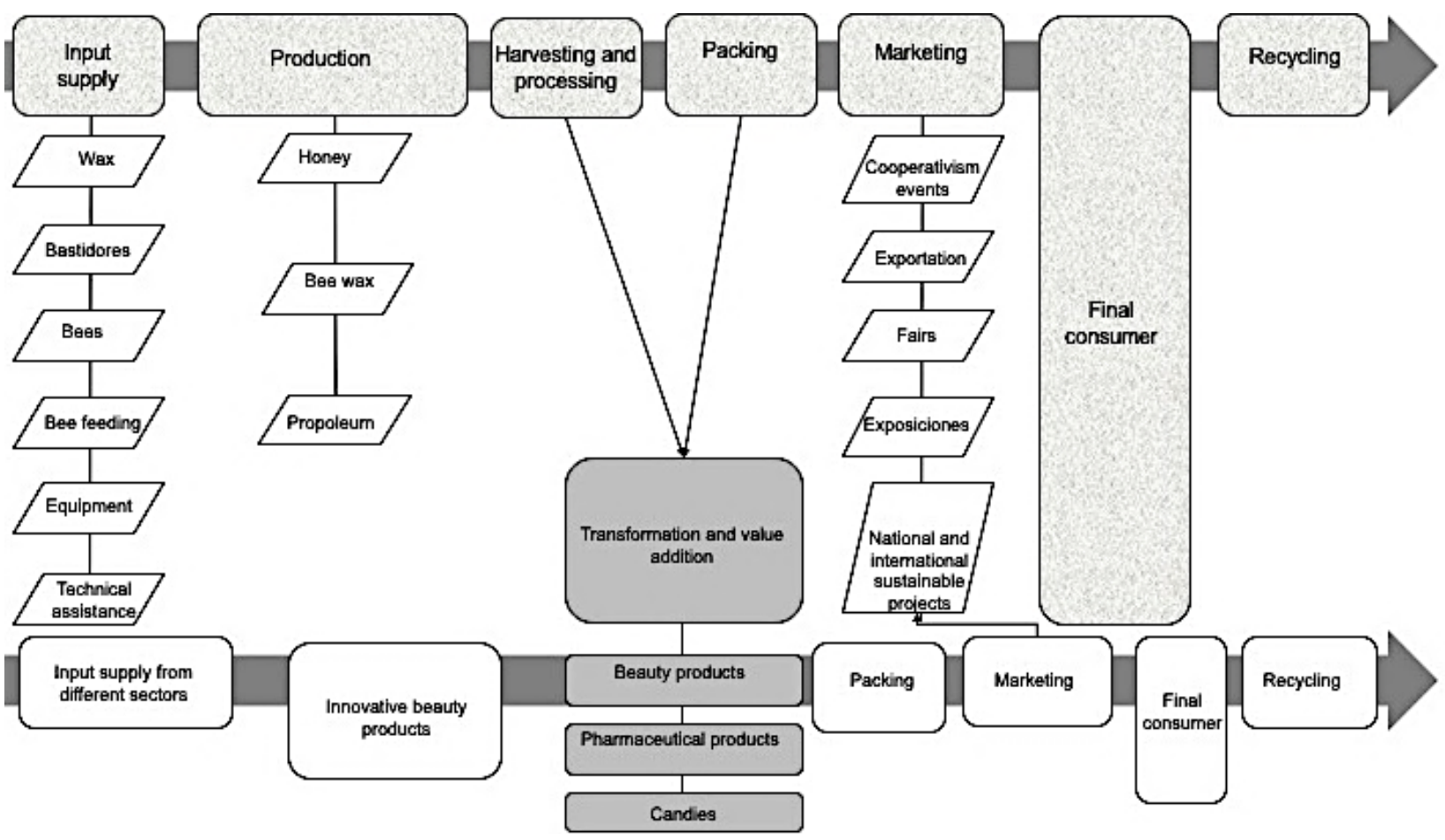

Figure 6. Value chain cooperative society Cepra Miel SC de RL de CV.

On the one hand, the promotion of honey with information on its characterization has opened avenues for local products (exports) to meet international standards [20-22]. On the other hand, the quality of honey is mainly determined by its sensory, physicochemical and microbiological characteristics [4]. The sensorial characteristics are measurement and quantified through the senses. The parameters analyzed in this case are the following: color, odor, aroma, taste and texture. The criteria for the physicochemical quality of honey are well specified by the European Community Guidelines 2001/110 [4]. Many studies have been reported on the sensory [23], physicochemical [4, 23, 24, 25] and microbiological [4] characteristics of honey from different countries. Some studies have reported the physicochemical characteristics of Mexican honey from the Southwest [26-29] and West region [30]. Unfortunately, there is no reported 
information from other Mexican regions, particularly the characterization of Mexico City honey is lacking. Therefore, this study aims to contribute to the knowledge of the quality of commercial honeys of Apis Mellifera that is produced and marketedby cooperative societies in Mexico City, through a sensory and a physicochemical analysis.Sampling took place at three different geographical locations in South Mexico City. It is hope that information gathered would help recognize genuine honeys produced by cooperative societies located in Mexico City and revalue them.

\section{Materials and Method}

\subsection{Study Area}

Mexico City is part of the Altiplano honey production region of Mexico. Samples of honey were collected in three phytogeographical zones (Tláhuac, Milpa Alta, and Xochimilco) of South of Mexico City (see Figure 7). Mexico City is located in an endorheic lake basin surrounded by mountain chains and cover an area of $1485 \mathrm{~km}^{2}$ [31]. The city is bounded by the coordinates $19^{\circ} 03^{\prime}$ to $19^{\circ} 36^{\prime} \mathrm{N}$ and $98^{\circ} 57^{\prime}$ to $99^{\circ} 22^{\prime} \mathrm{W}$. The northeast of the city tends to be dryer with 400 to $500 \mathrm{~mm}$ annual precipitation, while the Center and South receive 700 to $1,200 \mathrm{~mm}$ precipitation annually [31, 32]. Land is divided into Central-Northern part (45\%), which is urbanized, and South and West (55\%), which are rural whose main industries are forest products and agriculture [31].

\subsection{Honey Sample Collection}

All collected samples were harvested by the cooperative societies between fall 2018 and fall 2019 (see Figure 8). All samples were kept in sterile vials, hermetically sealed, labelled, dated and transferred to the laboratory of the Bee Team, El Colegio de la Frontera Sur located in San Cristobal de las Casas, Chiapas, Mexico, where they were store at room temperature $\left(25-30^{\circ} \mathrm{C}\right)$ until analysis.

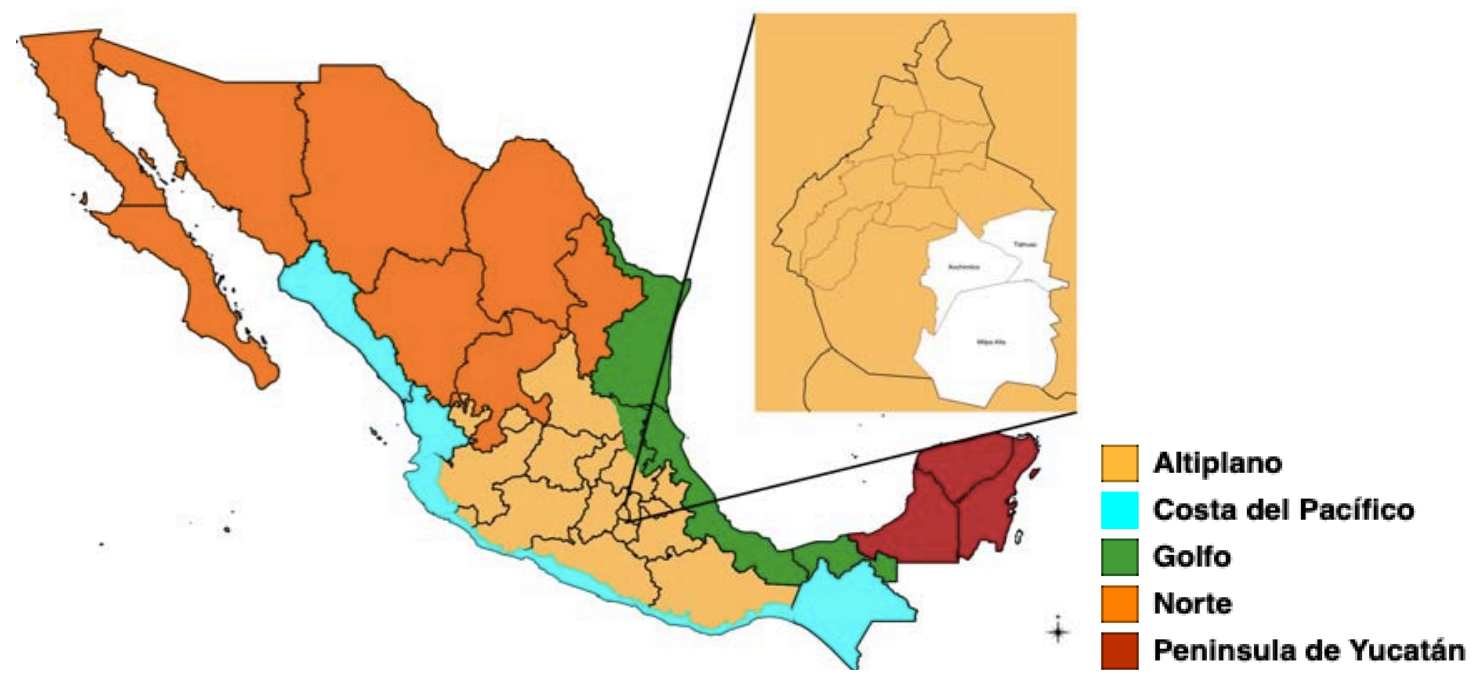

Figure 7. Three phytogeographical zones (Tláhuac, Milpa Alta and Xochimilco) of South of Mexico City where honey samples were collected.

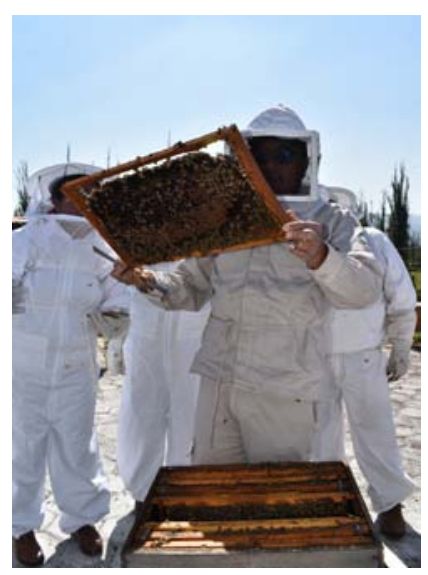

Figure 8. Field work for collecting sample of honey. 


\subsection{Physicochemical Characterization}

The physicochemical characteristics of honey are a routine laboratory analysis that provides quantitative results of different elements of honey and allows for approximate estimation of the presence of honey blend [20]. In 2018, the Mexican legislation published the PROY-NOM-004-SAG/GAN-2018, an Official Mexican Standard that establishes the general characteristics for the production of honey that promote the care of honey bees and their correct development, as well as the specifications that honey must meet for its commercialization, whether for direct consumption and/or processing; in order to contribute to the development of national beekeeping and the competitiveness of the honey chain [33]. This standard is mandatory for individuals or companies that are engaged in the production and/or marketing of national or imported honey from honey bees, which is marketed or is intended to be marketed within the territory of the United Mexican States in its different presentations, whose name must correspond to that established in this Official Mexican Standard. The physicochemical parameters included in this study, based on the Official Mexican Standard, are the following. All methods used to measure the physicochemical parameters are referenced in PROY-NOM-004-SAG/ GAN-2018.

\subsubsection{Color}

On the one hand, the color of honey is one of the most variable characteristics and represents a classification criterion for monofloral honeys [26]. From the marketing point of view, it is of great importance since the honey price and the degree of consumer acceptance depends on it [26]. On the other hand, color of honey is related to the botanical origin, the composition of the nectar in terms of pollen and minerals, the production and harvesting processes, temperature and even the storage time [34,35]. The color depends on the presence of pigments such as carotene and xanthophylls and the presence of flavonoid-type polyphenols [26]. The color is measured according to Pfund colour scale. The measurement is expressed in millimeters (mm).

\subsubsection{Water content}

It is one of the most important measurements since water content influences the specific weight, viscosity and flavor, conditioning the conservation, palatability, solubility and commercial value [26]. Water content can be measurement using an Abbé digital refractometer [34]. It is expressed in percentage.

\subsubsection{Electrical conductivity}

It is a good criterion of the botanical origin of honey [36], it is determined by factors as soil, weather, and floral physiology [26]. In fact, it allows to distinguish honey from flower nectar and honeydew [26]. The measurement in miliSiemens $/ \mathrm{cm}(\mathrm{mS} / \mathrm{cm})$, depends on the ash and acid content, being linear the relationship between the ash content and the electrical conductivity [3].

\subsection{4 pH.}

This parameter determines the acidic nature of honey [37], due to the presence of organic acids, being the main the gloconic acid that do not permit the deterioration by microorganisms [26].

\subsubsection{Total acidity}

Honey acidity is considered to be one of the factors that contributes to its antimicrobial activity [38]. The acidy of honey creates an environment that facilitates the release of axigen from the hemoglobin that is required for newly growing cells and the stimulation of white blood cells [38]. It is calculated as free acidity plus lactone. It is expressed in miliequivalents per kilogram of honey (meq/kg).

\subsubsection{Free acidity}

It is the sum of all the free acids expressed in miliequivalents per kilogram (meq/kg) of honey [4].

\subsubsection{Lactone}

Honey lactones vary irregularly $[38,39]$ and their determination is interesting because their hydrolysis increase free acid [39]. It is expressed in miliequivalents per kilogram (meq/kg) of honey.

\subsubsection{Reducing sugars}

The content of reducing sugar depends upon different factors as for example storage time and even time of collection of honey [40]. The sugar content of honey is mainly fructose, glucose, and sucrose, it is important to note that fructose is the sugar responsible for the sweetness of honey while glucose content depends upon the source of nectar [40]. It is expressed in\% (g/100g).

\subsection{Sensory Characterization}

It refers to the measurement and quantification of the characteristics of honey through the senses [26]. This study uses the method proposed by [26]. 


\subsubsection{Method}

According to F. Utrera Quintana et al. [26], firstly is evaluated the visual appearance that includes the physical state, appearance and color. Secondly, the odor, which is given by the presence of aromatic compounds using the "wheel of odors and aromas". Thirdly, the aroma is evaluated, that is honey is tasted through the mouth and the aroma is perceived through the nasal cavities. After that, the texture of honey. Finally, the taste which can be sweet, sour, bitter or salty.

\section{Results and Discussion}

\subsection{Physicochemical and Sugar Characteristics}

\subsubsection{Color}

Table 1 presents the color of examined samples, classified according to the Official Mexican Standard PROY-NOM-004-SAG/GAN-2018. In studied honey samples, the color ranged from Light amber for cooperative society 2 honey to Extra light amber for cooperative society 1 and 3.

Table 1. Color value of honey according to the cooperative societies and the Official Mexican Standard

$$
\text { Cooperative society } 1 \quad \text { Cooperative society } 2 \text { Cooperative society } 3 \text { Official Mexican Standard }{ }^{1} \text { [33] }
$$

\begin{tabular}{|c|c|c|c|c|}
\hline Color (mm Pfund) & $\begin{array}{c}47 \\
\text { Extra light amber }\end{array}$ & $\begin{array}{l}53 \\
\text { Light amber }\end{array}$ & $\begin{array}{l}41 \\
\text { Extra light amber }\end{array}$ & $\begin{array}{l}\text { White water } \\
\text { Extra white } \\
\text { White } \\
\text { Extra light amber } \\
\text { Light amber } \\
\text { Amber } \\
\text { Dark amber }\end{array}$ \\
\hline
\end{tabular}

1 PROY-NOM-004-SAG/GAN-2018.

\subsubsection{Water content}

In the examined samples, the cooperative society 2 and cooperative society 3 honey samples showed the highest water content value (see Table 2) and out of the Official Mexican Standard limit [33] that does not insure honey conservation and this fact decreases its commercial value.

Table 2. Water content of honey according to the cooperative societies and the Official Mexican Standard

\begin{tabular}{ccccc}
\hline & Cooperative society & Cooperative society & Cooperative society & 3 \\
\hline $\begin{array}{c}\text { Water content } \\
(\%)\end{array}$ & 1 & 2 & 21.6 & $\begin{array}{c}\text { Official Mexican Standard } \\
\text { value }^{1}[33]\end{array}$ \\
\hline
\end{tabular}

\subsubsection{Electrical conductivity}

In the present study, the electrical conductivity of the examined honey samples were 0.29 for cooperative society 1 , 0.28 for cooperative society 2 and 0.32 for cooperative society 3 (see Table 3 ). All honey samples within the Official Mexican Standard limit.

Table 3. Electrical conductivity of honey according to the cooperative societies and the Official Mexican Standard

\begin{tabular}{ccccc}
\hline & $\begin{array}{c}\text { Cooperative } \\
\text { society 1 }\end{array}$ & $\begin{array}{c}\text { Cooperative } \\
\text { society 2 }\end{array}$ & $\begin{array}{c}\text { Cooperative } \\
\text { society 3 }\end{array}$ & $\begin{array}{c}\text { Official Mexican Standard } \\
\text { value }^{1} \text { [33] }\end{array}$ \\
\hline $\begin{array}{c}\text { Electrical conductivity } \\
(\mathrm{mS} / \mathrm{cm})\end{array}$ & 0.29 & 0.28 & 0.32 & 0.8 maimum. \\
\hline
\end{tabular}

\subsection{4 pH}

The $\mathrm{pH}$ values of honey samples were measured and the obtained results confirmed that, all tested samples were acidic (pH 3.74-3.94) and within the standard limit [1] (see Table 4).

Table 4. pH value of honey according to the cooperative societies and the Codex Alimentations 2001 [1]

\begin{tabular}{ccccc}
\hline & $\begin{array}{c}\text { Cooperative society } \\
1\end{array}$ & $\begin{array}{c}\text { Cooperative } \\
\text { society 2 }\end{array}$ & $\begin{array}{c}\text { Cooperative } \\
\text { society 3 }\end{array}$ & $\begin{array}{c}\text { Codex Alimenta- } \\
\text { tions, 2001 [1] }\end{array}$ \\
\hline $\mathrm{pH}$ & 3.94 & 3.82 & 3.74 & $3.4-6.1$ \\
\hline
\end{tabular}




\subsubsection{Total acidity}

In the present study, the total acidity of all samples was within the acceptable range (40 maximum) according to the Official Mexican Standard value. Cooperative society 3 honey sample showed the highest value of total acidity (see Table 5).

Table 5. Total acidity value of honey according to the cooperative societies and the Official Mexican Standard

\begin{tabular}{ccccc}
\hline & $\begin{array}{c}\text { Cooperative society } \\
1\end{array}$ & $\begin{array}{c}\text { Cooperative society } \\
\text { Cooperative society }\end{array}$ & $\begin{array}{c}\text { Official Mexican Standard value } \\
\text { [33] }\end{array}$ \\
\hline $\begin{array}{c}\text { Total acidity } \\
\text { (meq } / \mathrm{kg})\end{array}$ & 26 & 24 & 31.5 & 40 maximum \\
\hline
\end{tabular}

\subsubsection{Free acidity}

The free acidity value of honey samples ranged from 19 cooperative society 2 honey to 25 cooperative society 1 honey (see Table 6).

Table 6. Free acidity value of honey according to the cooperative societies and the Codex Alimentations 2001 [1]

\begin{tabular}{lcccc}
\hline & Cooperative society 1 & Cooperative society 2 & Cooperative society 3 & Codex Alimentations, 2001 [1] \\
\hline Free acidity (meq $/ \mathrm{kg})$ & 25 & 19 & 24.5 & $<50$ \\
\hline
\end{tabular}

\subsubsection{Lactone}

In the present study, the lactone value for honey samples ranged from 1 of cooperative society 1 honey to 7 of cooperative society 3 honey. Lactone value of all samples was within the acceptable range (2.8-11.5), except for cooperative society 1 which was not accepted by codex range [1] (see Table 7).

Table 7. Lactone value of honey according to the cooperative societies and the Codex Alimentations 2001 [1]

\begin{tabular}{ccccc}
\hline & Cooperative society 1 & Cooperative society 2 & Cooperative society 3 & Codex Alimentations, 2001 [1] \\
\hline Lactona $(\mathrm{meq} / \mathrm{kg})$ & 1 & 5 & 7 & $2.8-11.5$ \\
\hline
\end{tabular}

\subsubsection{Reducing sugars}

The reducing sugars for all investigated samples were 70.42, 66.23, and 68.97 for cooperative society 1 , cooperative society 2, cooperative society 3 honey, respectively (see Table 8).

Table 8. Reducing sugars value of honey according to the cooperative societies and the Official Mexican Standard

\begin{tabular}{ccccc}
\hline & $\begin{array}{c}\text { Cooperative } \\
\text { society } 1\end{array}$ & $\begin{array}{c}\text { Cooperative society } \\
2\end{array}$ & $\begin{array}{c}\text { Cooperative society } \\
\text { (3) }\end{array}$ & \multicolumn{2}{c}{$\begin{array}{c}\text { Official Mexican Standard value }{ }^{1} \\
\text { [33] }\end{array}$} \\
\hline $\begin{array}{c}\text { Reducing sugars } \\
(\% \mathrm{~g} / 100 \mathrm{~g})\end{array}$ & 70.42 & 66.23 & 68.97 & $60-75$ \\
\hline
\end{tabular}

\subsection{Sensory Characteristics}

The sensory characteristics are similar for all samples (see Table 9).

Table 9. Sensory characteristics of honey samples

\begin{tabular}{cccc}
\hline & Cooperative society 1 & Cooperative society 2 & Cooperative society 3 \\
\hline Visual appearance & Homogeneous & Homogeneous & Homogeneous \\
Odor & Fresh-fruit & Fruity and veegtable & Fresh-fruit \\
Taste & Sweet & Sweet & Sweet \\
Aroma & Warm-processed fuit & Fresh-fruit & Fresh-fruit \\
Texture & Pasty & Pasty & \\
\end{tabular}

\section{Conclusions}

This study provided information on the quality status of honey produced in Mexico City by three cooperative socie- 
ties by analyzing color, water content, electrical conductivity, $\mathrm{pH}$, total acidity, free acidity, lactone, reducing sugars and sensory characteristics such as visual appearance, odor, taste, aroma and texture. All tested honey samples were within the Official Mexican Standard [33] and the Codex Alimentations, 2001 [1] limit, except cooperative society 2 honey and cooperative society 3 honey in water content value and cooperative society 1 honey in lactone value. Although the hives of the three cooperative societies are located in Mexico City, the sensory and physicochemical characteristics of honey were varied based on handling, transportation and storage condition, mainly. This study concludes that the commercial honey of Apis Mellifera produced and marketed by cooperative societies in Mexico City had a good level of quality.

\section{Acknowledgments}

This work was supported by UNAM-PAPIIT TA 101219. Authors appreciate Bee Team, El Colegio de la Frontera Sur, for its help in this work. Authors are also thankful to the three cooperative societies: Cepra Miel SC de RL de CV, ApiarioAtotolco SC de RL de CV, Construir en Raices SC de RL de CV, from this study that generously provided their time during the field work.

\section{References}

[1] Codex Alimentations. (2001). Draft revised standard for standard for honey (at step 10 of the Codex procedure). Alinorm 01 (25), 19-26.

[2] K. Komosinska-Vassev, P. Olczyk, J. Kazmierczak, L. Mencner, K. Olczyk. (2015). "Bee pollen: chemical composition an therapeutic application”, Evidence-Based Complementary and Alternative Medicine, Vol. 2015.

[3] S. A. El Sohaimy, S. H. D. Masry, M. G. Shehata. (2015). "Physicochemical characteristics of honey from different origins", Ann. Agric. Sci., 2015.

[4] F. E. Azonwade, A. Paraïso, C. P. AgbangnanDossa, V. T. Dougnon, C. N’tcha, W. Mousse, L. Baba-Mousa. (2018). "Physicochemical Characteristics andMicrobiological Quality of Honey Produced in Benin”, Journal of Food Quality, Vol. 2018.

[5] M. A. Kamaruzzaman, K. Chin, E. S. Mohd Ramli. (2019). “A Review of Potential Beneficial Effects of Honey on Bone Health”, Evidence-Based Complementary and Alternative Medicine, Vol. 2019.

[6] L. Suan Chua, N. L. A. Rahaman, N. Ardawati Adnan, T. T. Eddie Tan. (2013). "Antioxidant Activity of Three Honey Samples in relation with their Biochemical Components”, Journal of Analytical Methods in Chemistry, Vol. 2013.

[7] N. Shafin, Z. Othman, R. Zakaria, N. H. Nik Hussain. (2014). “Tualang Honey Supplementation Reduces Blood Oxidative Stress Levels/Activities in Postmenopausal Women”, ISRN Oxidative Medicine, Vol. 2014.

[8] F. A. Zulkhairi Amin, S. Sabri, S. Malihah Mohammad, M. Ismail, K. Wei Chan, N. Ismail, M. EsaNorhaizan, N. Zawaai. (2018). "Therapeutic Properties of Stingless Bee Honey in Comparison with European Bee Honey”, Advances in Pharmacological Sciences, Vol. 2018.

[9] N. Hayati Othman. (2012). "Honey and Cancer: Sustainable Inverse Relationship Particularly for Developing Nations-A Review”, Evidence -Based Complementary and Alternative Medicine, Vol. 2012.

[10] M. E. M. Campeau, R. Patel. (2014). “Antibiofilm Activity of Manuka Honey in Combination with Antibiotics”, International Journal of Bacteriology, Vol. 2014.

[11] D. P. Mohapatra, V. Thakur, S. K. Brar. (2011). “Antibacterial Efficacy of Raw and Processed Honey”, Biotechnology Research International, Vol. 2011.

[12] N. A. Albaridi. (2019). “Antibacterial Potency of Honey”, International Journal of Microbiology, Vol. 2019.

[13] S. H. Safii, G. R. Tompkins, W. J. Duncan. (2017). "Periodontal Application of Manuka Honey: Antimicrobial and Demineralising Effects In Vitro”, International Journal of Dentistry, Vol. 2017.

[14] N. Mohd Effendy, N. Mohamed, N. Muhammad, I. Naina Mohamad, A. NazrunShuid. (2012). "The Effects of Tualang Honey on Bone Metabolism of Postmenopausal Women”, Evidence-Based Complementary and Alternative Medicine, Vol. 2012.

[15] S. Ahmed, N. Hayati Othman. (2013). "Honey as a Potential Natural Anticancer Agent: A Review of Its Mechanisms”, Evidence-Based Complementary and Alternative Medicine, Vol. 2013.

[16] M. Magaña, A. Aguilar, P. Lara y J. Sanginés, J. (2007). “Caracterización socioeconómica de la actividad apícola en el estado de Yucatán, México”, Agronomía, Universidad de Caldas, Colombia, Vol. 15, No. 2, 17-24.

[17] L. E. Soto-Muciño, C. Chiatchoua, Y. Castañeda-González. (2015). “National and International Panorama of Honey Production in Mexico", ECORFAN Journal, Vol. 1, No. 1.

[18] Atlas Nacional de las Abejas y Derivados Apícolas 2017. (2020). https://atlasapi2019.github.io/index.html.

[19] Catálogo de Cooperativas de la Ciudad de México. (2019). http://www.cooperativas.cdmx.gob.mx/styfe/coop100/catalogo.php.

[20] C. I. A. Nwoko, A. U. Nkwoada, E. O. Ubeh, A. Njoku. (2017). “Characterization of Selected Honey in South-East Nigeria: 
Theoretical Translation”, International Journal of Environment, Agriculture and Biotechnology (IJEAB), Vol. 2.

[21] P. Mondragón-Cortez, J. A. Ulloa, P. Rosas-Ulloa, R. Rodríguez-Rodríguez, J. A. Resendiz Vázquez. (2013). "Physicochemical characterization of honey from the West region of México, CyTA”, Journal of Food, Vol. 11, No. 1.

[22] L. B. Almeida-Muradian, K. M. Stramm, A. Horita, M. O. Barth, S. A. Freitas, L. M. Leticia M. Estevinho. (2013). “Comparative study of the physicochemical and palynological characteristics of honey from Meliponasubnitida and Apismellifera", International Journal of Food Science and Technology, Vol. 48.

[23] C. O. Eleazu, M. Iroaganachi, and J. Okoronkwo. (2013). "Determination of the physicochemical composition, microbial quality and free radical scavenging activities of some commercially sold honey samples in Aba, Nigeria: The effect of varying colors”, Journal of Nutriition and Food Science, Vol. 3, No. 2.

[24] H. M. Kumar Manu, A. P. Ananda, D. Vishwanathan, and Siddagangaiah. (2013). "Study of Physicochemical parameters and Antioxidant in Honey collected from different locations of India”, International Journal of Pharmacy and Life Sciences, Vol. 4 , No. 12, 3159-3165.

[25] S. Mekious, Z. Houmani, E. Bruneau, C. Masseaux, A. Guillet, and T. Hance. "Caracterisation des mielsproduits dans la ré gionsteppique de DjelfaenAlgé rie”, Biotechnology. Agronomy. Soci- ety and Environment, Vol. 19, No. 3, $221-231$.

[26] F. Utrera Quintana, A. Arroyo Vázquez, E. R. Tanus Sánchez, J. O. Torres Bocanegra. (2018). "La apicultura: actividad sustentable”, Asociación Nacional de Médicos Veterinarios Especialistas en Abejas.

[27] Y. Mogel-Ordoñez, C. Echatarreta-González and R. Mora-Escobedo. (2005). "Calidad fisicoquímica de la miel de abeja Apis Mellifera producida en el estado de Yucatán durante diferentes etapas del proceso de producción y tipos de floración”, Técnica Pecuaria en México, Vol. 43, 323-334.

[28] R. Mora-Escobedo, Y. Mogel-Ordoñez, M. E. Jaramillo-González, and G. F. Gutiérrez-López. (2006). “The composition, rheological and thermal properties of Tajonal (Viguiera dentata) Mexican honey”, International Journal of Food Properties, Vol. 9, 299-316.

[29] M. Viuda-Martos, Y. Ruiz-Navajas, J. M. Zaldivar-Cruz, et al. (2010). “Aroma profile and physico-chemical properties of artisanal honey from Tabasco, Mexico”, International Journal of Food Science and Technology, Vol. 45, 1111-1118.

[30] P. Mondragón-Cortez, J. A. Ulloa, P. Rosas-Ulloa, R. Rodríguez-Rodríguez, J. A. ResendizVázuqez. (2013). “Physicochemical charcaterization of honey from the West region of Mexico”, CyTA- Journal of Food, Vol. 11.

[31] F. Estrada, A. Martínez-Arroyo, A. Fernández-Eguiarte, E. Luyando, C. Gay. (2009). "Defining climate zones in Mexico City using multivariate analysis”, Atmósfera, Vol. 22, No. 2.

[32] E. Jáuregui. (2000). El clima de la ciudad de México. Instituto de Geografía, UNAM-Plaza y Valdés. México, p. 131.

[33] PROYECTO de Norma Oficial Mexicana PROY -NOM-004-SAG/GAN-2018, Producción de miel y especificaciones , DOF, 2018 .

[34] S. Bogdanov, K. Ruoff, L. Persano. (2004). "Physicochemical methods for the characterization of unifloral honeys: A Review", Apidologie, Vol. 35.

[35] A. Terrab, L. González-Miret, F. J. Heredia. (2004). "Colourcharacterisation of thyme and avocado honeys by diffuse reflectance spectrophotometry and spectroradiometry”, Eur. Food Res. Technol., Vol. 218.

[36] M. O. Adenekan, N. A. Amusa, A. O. Lawal, V. E. Okpeze. (2010). "Physico-chemical and microbiological properties of honey samples obtained from Ibadan”, J. Microbiol. Antimicrobial, Vol. 2, No. 8, 100-104.

[37] V. Nanda, B. C. Sarkar, H. K. Sharma, and A. S. Bawa. (2003). "Physico- chemical properties and estimation of mineral content in honey produced from different plants in Northern India”, Journal of Food Composition and Analysis, Vol. 16, No. 5, 613-619.

[38] M. M. Cavia, M. A. Fernández-Muiño, S. R. Alonso-Torre, J. F. Huidobro, M. T. Sancho. (2007). "Evolution of acidity of honeys from continental climates: Influence of induced granulation”, Analytical, Nutritional and Clinical Methods, Vol. 100, 1728-1733.

[39] J. W. White, J. Petty, and R. B. Hager. (1958). “The composition of honey. II. Lactone Content”, Journal of AOAC International, Vol. 41, No. 1, 194-197.

[40] H. I. Aljohar, H. M. Maher, J. Albaqami, M. Al-Mehaizie, R. Orfali, R. Orfali, S. Alrubia. (2018). "Physical and chemical screening of honey samples available in the Saudi market: An important aspect in the authentication process and quality assessmen”, Saudi Pharm J., Vol. 26, No. 7, 932-942. 